\title{
Characterization of Brazilian wheat cultivars for specific technological applications
}

\author{
Caracterização de cultivares brasileiras de trigo, com indicação de aplicabilidade tecnológica
}

\author{
Patrícia Matos SCHEUER ${ }^{1 \star}$, Alicia de FRANCISCO ${ }^{1}$, Martha Zavariz de MIRANDA $^{2}$, Paulo José OGLIARI ${ }^{1}$, \\ Gisele TORRES ${ }^{2}$, Valéria LIMBERGER ${ }^{1}$, Flávio Martins MONTENEGRO ${ }^{3}$, Cristiane Rodrigues RUFFI $^{3}$, Sílvia BIONDI ${ }^{3}$
}

\begin{abstract}
Functional and technological properties of wheat depend on its chemical composition, which together with structural and microscopic characteristics, define flour quality. The aim of the present study was to characterize four Brazilian wheat cultivars (BRS Louro, BRS Timbauva, BRS Guamirim and BRS Pardela) and their respective flours in order to indicate specific technological applications. Kernels were analyzed for test weight, thousand kernel weight, hardness, moisture, and water activity. Flours were analyzed for water activity, color, centesimal composition, total dietary fiber, amylose content and identification of high molecular weight glutenins. The rheological properties of the flours were estimated by farinography, extensography, falling number, rapid visco amylography, and glutomatic and glutork equipment. Baking tests and scanning electron microscopy were also performed. The data were subjected to analysis of variance and principal component analysis. BRS Timbauva and BRS Guamirim presented results that did not allow for specific technological application. On the other hand, BRS Louro presented suitable characteristics for the elaboration of products with low dough strength such as cakes, pies and biscuits, while BRS Pardela seemed suitable for bread and pasta products.

Keywords: wheat; composition; rheology; baking.
\end{abstract}

\section{Resumo}

A composição química do grão de trigo afeta as características funcionais tecnológicas e, juntamente com as propriedades estruturais e microscópicas, define a qualidade da farinha de trigo. Assim, este trabalho tem como objetivo caracterizar amostras de cultivares de trigo e respectivas farinhas, BRS Louro, BRS Timbaúva, BRS Guamirim e BRS Pardela, visando indicar a aplicabilidade tecnológica. As amostras das cultivares foram caracterizadas fisicamente quanto ao peso do hectolitro, peso de mil grãos, textura, umidade e atividade de água. As farinhas foram caracterizadas quanto aos aspectos físico-químicos, atividade de água, cor, composição centesimal, teor de amilose e identificação das gluteninas de alto peso molecular. As farinhas foram caracterizadas de acordo com aspectos reológicos, granulometria, farinografia, extensografia, número de queda, viscosidade, propriedades do glúten, panificação experimental, e quanto aos aspectos microscópicos. Os dados foram submetidos à análise de variância à análise de componentes principais. As cultivares BRS Timbaúva e BRS Guamirim possuem comportamentos que não permitem direcionar à aplicação tecnológica com tanta veemência. A cultivar BRS Louro possui características à elaboração de produtos com massa de glúten fraco como bolos, tortas e biscoitos e a BRS Pardela, adequada para produtos de panificação e massas em geral.

Palavras-chave: trigo; composição; reologia; panificação.

\section{Introduction}

Wheat (Triticum aestivum L.) is one of the three most important crops of the world concerning harvested area (CURTIS; RAJARAM; MACPHERSON, 2002) and it is the main staple food for approximately $35 \%$ of the world's population (TORRES, 2008).

The chemical composition of the kernel affects technological and functional characteristics that, together with microstructural properties, define the quality of the wheat flour (MOUSIA et al., 2004).

Generally, wheat flour is composed of starch (70 to $75 \%$ ), water (12 to $14 \%$ ), proteins ( 8 to $16 \%$ ), and minor constituents such as fiber (2 to $3 \%)$, lipids (2\%) and minerals (1\%). Therefore, variations in quality and quantity of grain components will affect the quality of flour (MORITA et al., 2002), for a given end product.

Wheat flour is unique among other cereals flours due to its capacity to form a three-dimensional web-like structure and viscoelastic dough when mixed with water (SONG; ZHENG, 2007). This fact makes wheat flour the most important structural component for baking as it is responsible for trapping the gas produced during fermentation, resulting in spongelike foodstuff (HOSENEY, 1991). As the grain structure and composition determine the characteristics of the flour, the aim of this study was to characterize grains and flours from four different Brazilian wheat cultivars obtained and recommended

${ }^{1}$ Federal University of Santa Catarina, UFSC, Rod. Admar Gonzaga, 1346, Itacorubi, CEP 88034-001, Florianópolis - SC, Brazil, E-mail: patriciamatosscheuer@hotmail.com

2 Brazilian Agricultural Research Corporation, Passo Fundo - Embrapa, Rod. BR 285, Km 294, CEP 99001-970, Passo Fundo - RS, Brazil

${ }^{3}$ Food Technology Institute, Campinas, Av. Brasil, 2880, CP 139, CEP 13070-178, Campinas - SP, Brazil

* Corresponding author 
by Embrapa (Empresa Brasileira de Pesquisa Agropecuária), harvested in 2008 , in order to determine their end-use.

\section{Materials and methods}

Each analysis was performed three times and carried out in triplicate.

\subsection{Grain samples and physical tests}

Grain samples of four different Brazilian wheat cultivars (BRS Louro, BRS Timbaúva, BRS Guamirim and BRS Pardela) harvested in 2008 were supplied by Embrapa. The samples were stored in cold room at $4{ }^{\circ} \mathrm{C}$ until use.

Physical characterization of the kernels included: test weight, determined with a Dalle Molle weighing scale, following the equipment handbook (BRASIL, 1992); thousand kernel weight, according to the method described in Brasil (1992); kernel hardness; kernel moisture; and kernel water activity, according to Table 1. For the water activity determination of kernels, Aqualab equipment - Decagon, was used according to the equipment manual.

\subsection{Milling and flour sample analysis}

All grain samples were milled in order to obtain the flour samples, which were stored at $4{ }^{\circ} \mathrm{C}$ until use. All flour samples were analyzed for: granularity, color, moisture, total protein content, total dietary fiber, total starch, lipid and ash, according to the Table 1 . Water activity was analyzed using Aqualab equipment - Decagon, according to the equipment manual. Amylose content was determined by the Iodine Blue
Value method (GILBERT; SPRAGG, 1964). Glutenin molecular weight was determined by SDS-PAGE (PAYNE; LAWRENCE, 1983) and gel staining (BLAKESLEY; BOEZI, 1977) after storage protein extraction (SINGH; SHEPHERD; CORNISH, 1991).

\subsection{Flour rheological characterization}

The rheological analyses were the following: farinography, extensography, falling number, wet gluten and dry gluten, according to Table 1 . The viscosity of flour slurries was determined thorough an RVA-3D equipped with the Termocline program for Windows 3.1, according to the equipment manual (NEWPORT SCIENTIFIC, 1998) and Table 1.

\subsection{Baking test and bread formulation}

Baking test was determined according to El-Dash (1978). Bread formulation consisted of ( $\mathrm{g} .300 \mathrm{~g} \mathrm{~g}^{-1}$ wheat flour): salt $(5.25 \mathrm{~g})$, sugar $(15.0 \mathrm{~g})$, fresh leaven $(9.0 \mathrm{~g})$, hydrogenated vegetable fat $(9.0 \mathrm{~g})$, and L-ascorbic acid (0.027 g). After baking and cooling, bread volume was determined through the rapeseed displacement method, AACC (AMERICAN ASSOCIATION OF CEREAL CHEMISTS INTERNATIONAL, 2000) method 10-05.01. For bread quality evaluation, the classification table of Camargo and Camargo (1987) was used.

\subsection{Scanning electron microscopy}

Wheat flour samples were grouped with double-sided adhesive tape on aluminum stubs and sputter-coated with $200 \mathrm{~A}^{\circ}$ of gold. A JEOL JSM-6390LV scanning electron microscope operated with accelerating voltage of $10 \mathrm{kV}$ was

Table 1. American Association of Cereal Chemists approved methods (2000).

\begin{tabular}{|c|c|c|}
\hline Analysis & Number & Equipment used \\
\hline \multicolumn{3}{|l|}{ Physical Tests } \\
\hline Kernel hardness & $55-31$ & determined by the Single Kernel Classification System (SKCS) \\
\hline Kernel moisture & $44-10$ & determined with Dickey John humidity instrument \\
\hline Grains' milled & $26-10 \mathrm{~A}$ & with quadramet Senior mill, Brabender \\
\hline \multicolumn{3}{|l|}{ Flour Sample Analysis } \\
\hline Flour granulometry & $66-20$ & \\
\hline Flour color & $14-22$ & with CIELab system using Konica Minolta CR400 colorimeter \\
\hline Flour moisture content & $44-15 \mathrm{~A}$ & \\
\hline Flour total protein & $46-10$ & \\
\hline Flour total dietary fiber & $32-05$ & \\
\hline Flour total starch & $76-13$ & \\
\hline Flour lipid & $30-25$ & \\
\hline Flour ash & $08-01$ & \\
\hline \multicolumn{3}{|l|}{ Rheological analysis } \\
\hline Flour granulometry & $66-20$ & \\
\hline Farinograph & $54-21$ & with Brabender equipment \\
\hline Extensograph & $54-10$ & with Brabender equipment \\
\hline Falling number & $56-81 B$ & with a Falling Number, Perten Instruments $A B$ \\
\hline Viscosity & $76-21$ & \\
\hline $\begin{array}{l}\text { Wet gluten } \\
\text { Dry gluten } \\
\text { Gluten index }\end{array}$ & $38-12$ & with a Glutomatic by Perten Instruments AB, centrifugal model 2015 and Glutork model 2020 \\
\hline
\end{tabular}


used for the observations and the images were directly stored in the system.

\subsection{Statistical analysis}

Data were submitted to analysis of variance (ANOVA), Tukey's test (significance level $\mathrm{p} \leq 0.05$ ) and principal component analysis (PCA). Statistical analysis and graphical representations were performed using STATISTICA 7.0 software, Copyright StatSoft, Inc. 1984-2004.

\section{Results}

\subsection{Physical characterization of cultivars (Table 2)}

Results on the physical characterization showed that cultivar BRS Pardela presented test weight $\left(80.80 \mathrm{~kg} \cdot \mathrm{hL}^{-1}\right)$ significantly higher than the others $(\mathrm{p} \leq 0.05)$, and the highest flour extraction, $65.68 \%$. The four cultivars differed significantly ( $\mathrm{p} \leq 0.05$ ), in kernel hardness index and thousand kernel weight. BRS Timbaúva and BRS Pardela presented kernel hardness values higher than other cultivars. Cultivar BRS Louro presented the lowest value for thousand kernel weight (31.60 g), significantly lower extraction ( $\mathrm{p} \leq 0.05)(58.52 \%)$ and higher water activity (0.632) than the other cultivars. Kernel moisture did not present significant difference between cultivars $(\mathrm{p} \leq 0.05)$.

\subsection{Physicochemical characterization of flours (Table 2)}

Water activity of flour samples was significantly different between the studied cultivars $(\mathrm{p} \leq 0.05)$. Cultivar BRS Pardela presented the lowest value (0.588) and BRS Guamirim (0.675) the highest one. Wheat flour analysis presented variation in color components, with significant differences for color attributes chroma $\mathrm{L}^{*}, \mathrm{a}^{*}$ and $\mathrm{b}^{*}(\mathrm{p} \leq 0.05)$. The BRS Louro wheat flour presented the highest value of chroma $L^{*}(94.56)$ and BRS Timbaúva the highest value for chroma $b^{\star}$ (9.29). Moisture values of wheat flours from cultivars BRS Timbaúva (13.21\%) and BRS Guamirim (12.96\%) presented the same statistical result and both presented higher values than the other cultivars ( $\mathrm{p} \leq 0.05$ ). Starch content ranged from 77.44 to $81.92 \%$ (dry basis) regarding cultivars BRS Louro and BRS Pardela, respectively $(\mathrm{p} \leq 0.05)$. The wheat amylose content from cultivar BRS Timbaúva presented a significantly lower value $(\mathrm{p} \leq 0.05)$ than the other cultivars (19.42\%). Total protein content of flours ranged from $11.65 \%$ to $14.35 \%$, corresponding to cultivars BRS Louro and BRS Pardela, respectively. Total dietary fiber and ash content did not change significantly between the evaluated wheat flour cultivars ( $\mathrm{p} \leq 0.05$ ). Amount of lipids ranged from 0.9 to $1.04 \%$ (dry basis) for the four samples. Wheat flour cultivars BRS Louro and BRS Pardela did not present significant differences and the wheat flour cultivars BRS Timbaúva, BRS Guamirim and BRS Pardela did not present significant differences.

\subsection{Wheat storage protein extraction}

SDS-PAGE showed a $5+10$ and $17+18$ bands present only for the BRS Pardela cultivar.

\subsection{Rheological characterization of flours}

\section{Farinography and Extensography (Table 3)}

Water absorption content was observed in decreasing order for the cultivars: BRS Timbaúva $>$ BRS Guamirim > BRS Pardela $>$ BRS Louro. Flour from cultivar BRS Louro presented significantly lower values of mixing time, arrival time, departure time and stability when compared to the other cultivars; whereas

Table 2. Physical and chemical characterization of cultivars and flours.

\begin{tabular}{|c|c|c|c|c|}
\hline Variables & BRS Louro & BRS Timbaúva & BRS Guamirim & BRS Pardela \\
\hline TW (kg.hL $\left.{ }^{-1}\right)$ & $80.15^{b} \pm 0.00$ & $73.35^{\mathrm{c}} \pm 0.26$ & $73.33^{c} \pm 0.11$ & $80.80^{a} \pm 0.00$ \\
\hline TKW (g) & $31.60^{c} \pm 0.40$ & $34.43^{b} \pm 1.20$ & $36.53^{\mathrm{a}} \pm 0.87$ & $35.03^{\mathrm{ab}} \pm 0.21$ \\
\hline Hard & $36.38^{\mathrm{d}} \pm 0.22$ & $88.93^{a} \pm 0.93$ & $76.00^{b} \pm 0.44$ & $85.46^{c} \pm 0.48$ \\
\hline KM (\%) & $14.70^{\mathrm{a}} \pm 0.00$ & $13.10^{\mathrm{a}} \pm 0.00$ & $12.50^{\mathrm{a}} \pm 0.00$ & $14.60^{\mathrm{a}} \pm 0.00$ \\
\hline KWA & $0.632^{\mathrm{a}} \pm 0.001$ & $0.619^{d} \pm 0.0006$ & $0.625^{\mathrm{c}} \pm 0.001$ & $0.629^{b} \pm 0.001$ \\
\hline EXT (\%) & $58.52^{\mathrm{b}} \pm 1.103$ & $64.18^{\mathrm{a}} \pm 1.11$ & $62.42^{\mathrm{a}} \pm 0.64$ & $65.68^{a} \pm 0.516$ \\
\hline FWA & $0.601^{c} \pm 0.001$ & $0.636^{\mathrm{b}} \pm 0.002$ & $0.675^{\mathrm{a}} \pm 0.001$ & $0.588^{\mathrm{d}} \pm 0.001$ \\
\hline FM (\%) & $12.03^{b} \pm 0.29$ & $13.21^{\mathrm{a}} \pm 0.28$ & $12.96^{\mathrm{a}} \pm 0.31$ & $12.20^{\mathrm{b}} \pm 0.33$ \\
\hline$L^{*}$ & $94.56^{\mathrm{a}} \pm 0.14$ & $92.49^{\mathrm{d}} \pm 0.09$ & $93.37^{b} \pm 0.05$ & $93.00^{c} \pm 0.03$ \\
\hline$a^{*}$ & $-0.02^{b} \pm 0.026$ & $-0.17^{\mathfrak{c}} \pm 0.025$ & $-0.18^{c} \pm 0.017$ & $0.05^{\mathrm{a}} \pm 0.038$ \\
\hline$b^{*}$ & $6.56^{c} \pm 0.03$ & $9.29^{\mathrm{a}} \pm 0.01$ & $8.98^{\mathrm{b}} \pm 0.05$ & $8.98^{\mathrm{b}} \pm 0.03$ \\
\hline starch (\%) & $77.44^{b} \pm 1.55$ & $79.57^{\mathrm{ab}} \pm 2.17$ & $79.92^{\mathrm{ab}} \pm 5.17$ & $81.92^{\mathrm{a}} \pm 3.46$ \\
\hline $\mathrm{A}^{* *}$ & $21.50^{\mathrm{a}} \pm 1.43$ & $19.42^{b} \pm 0.55$ & $22.16^{\mathrm{a}} \pm 0.43$ & $20.46^{\mathrm{a}} \pm 0.31$ \\
\hline CP (\%) & $11.65^{c} \pm 0.16$ & $12.00^{\mathrm{bc}} \pm 0.09$ & $12.67^{\mathrm{b}} \pm 0.42$ & $14.35^{\mathrm{a}} \pm 0.40$ \\
\hline TDF (\%) & $2.67^{a} \pm 0.48$ & $2.45^{a} \pm 0.22$ & $2.91^{\mathrm{a}} \pm 0.60$ & $3.02^{\mathrm{a}} \pm 0.90$ \\
\hline ash (\%) & $0.95^{\mathrm{a}} \pm 0.024$ & $0.93^{a} \pm 0.029$ & $0.95^{\mathrm{a}} \pm 0.023$ & $0.95^{\mathrm{a}} \pm 0.024$ \\
\hline $\mathrm{Lp}(\%)$ & $1.04^{\mathrm{a}} \pm 0.30$ & $0.69^{b} \pm 0.06$ & $0.76^{\mathrm{b}} \pm 0.10$ & $0.85^{\mathrm{ab}} \pm 0.07$ \\
\hline
\end{tabular}

Samples: BRS Louro, BRS Timbaúva, BRS Guamirim and BRS Pardela. Mean values in the same line followed by a different letter are significantly different (p $\leq 0.05$ ). The variables are: TW, test weight; TKW, thousand kernel weight; Hard; KM, kernel moisture; KWA, kernel water activity; EXT, extraction; FWA, flour water activity; FM, flour moisture; L*, chroma L*; $\mathrm{a}^{*}$, chroma $\mathrm{a}^{*} ; \mathrm{b}^{*}$, chroma $\mathrm{b}^{*}$; starch; A, amylose; CP, crude protein; TDF, total dietary fiber; ash; Lp, lipids. ${ }^{* *}$ Percentage incorporated into the starch component. 
Scheuer et al.

Table 3. Rheological characterization of flours at farinograph and extensograph properties.

\begin{tabular}{|c|c|c|c|c|}
\hline Farinography/ extensography & BRS Louro & BRS Timbaúva & BRS Guamirim & BRS Pardela \\
\hline WA $(\%)$ & $53.57^{\mathrm{d}} \pm 0.17$ & $65.45^{\mathrm{a}} \pm 0.00$ & $61.43^{\mathrm{b}} \pm 0.00$ & $59.79^{c} \pm 0.00$ \\
\hline AT (minutes) & $1.00^{\mathrm{b}} \pm 0.00$ & $1.83^{\mathrm{ab}} \pm 0.29$ & $1.50^{\mathrm{ab}} \pm 0.00$ & $2.17^{\mathrm{a}} \pm 0.76$ \\
\hline MT (minutes) & $1.50^{\mathrm{d}} \pm 0.00$ & $2.50^{c} \pm 0.00$ & $3.00^{b} \pm 0.00$ & $10.50^{\mathrm{a}} \pm 0.00$ \\
\hline ST (minutes) & $2.00^{c} \pm 0.00$ & $2.30^{c} \pm 0.29$ & $7.00^{\mathrm{b}} \pm 0.00$ & $14.7^{\mathrm{a}} \pm 1.53$ \\
\hline MTI (FU) & $136.67^{\mathrm{a}} \pm 5.77$ & $110.00^{\mathrm{b}} \pm 0.00$ & $50.00^{c} \pm 0.00$ & $40.00^{\mathrm{d}} \pm 0.00$ \\
\hline $\mathrm{R}_{\mathrm{m}} 45(\mathrm{EU})$ & $127.50^{c} \pm 14.75$ & $101.67^{\mathfrak{c}} \pm 9.83$ & $351.67^{\mathrm{b}} \pm 7.53$ & $650.00^{\mathrm{a}} \pm 140.43$ \\
\hline $\mathrm{R}_{\mathrm{m}} 90(\mathrm{EU})$ & $135.00^{c} \pm 5.48$ & $111.67^{c} \pm 14.72$ & $493.30^{\mathrm{b}} \pm 35.02$ & $1000.00^{\mathrm{a}} \pm 0.00$ \\
\hline $\mathrm{R}_{\mathrm{m}} 135(\mathrm{EU})$ & $145.00^{c} \pm 15.16$ & $116.67^{c} \pm 14.72$ & $550.00^{\mathrm{b}} \pm 42.89$ & $1000.00^{\mathrm{a}} \pm 0.00$ \\
\hline R45 (EU) & $122.50^{c} \pm 11.73$ & $96.67^{c} \pm 10.33$ & $250.00^{\mathrm{b}} \pm 8.94$ & $453.33^{\mathrm{a}} \pm 101.32$ \\
\hline R90 (EU) & $126.67^{c} \pm 7.53$ & $105.00^{c} \pm 17.61$ & $400.00^{\mathrm{b}} \pm 76.94$ & $831.67^{\mathrm{a}} \pm 76.27$ \\
\hline R135 (EU) & $141.67^{c} \pm 18.35$ & $108.33^{c} \pm 16.02$ & $420.00^{\mathrm{b}} \pm 46.90$ & $1000.00^{\mathrm{a}} \pm 0.00$ \\
\hline $\mathrm{E} 45(\mathrm{~cm})$ & $146.33^{b} \pm 12.11$ & $159.17^{\mathrm{ab}} \pm 8.95$ & $168.00^{\mathrm{a}} \pm 4.73$ & $152.50^{\mathrm{ab}} \pm 13.81$ \\
\hline E90 $(\mathrm{cm})$ & $145.67^{\mathrm{b}} \pm 6.77$ & $171.83^{\mathrm{a}} \pm 3.92$ & $163.33^{\mathrm{a}} \pm 13.54$ & $127.83^{c} \pm 7.03$ \\
\hline $\mathrm{E} 135(\mathrm{~cm})$ & $129.50^{\mathrm{bc}} \pm 26.98$ & $182.33^{\mathrm{a}} \pm 17.95$ & $155.50^{\mathrm{ab}} \pm 13.72$ & $116.67^{\mathrm{c}} \pm 6.59$ \\
\hline $\mathrm{R} / \mathrm{E} 45$ & $0.84^{\mathrm{bc}} \pm 0.07$ & $0.61^{\mathrm{c}} \pm 0.05$ & $1.49^{\mathrm{b}} \pm 0.07$ & $3.02^{\mathrm{a}} \pm 0.88$ \\
\hline R/E 90 & $0.87^{c} \pm 0.045$ & $0.61^{c} \pm 0.105$ & $2.48^{\mathrm{b}} \pm 0.587$ & $6.54^{\mathrm{a}} \pm 0.905$ \\
\hline R/E 135 & $1.11^{\mathrm{c}} \pm 0.14$ & $0.60^{c} \pm 0.12$ & $2.73^{\mathrm{b}} \pm 0.45$ & $8.59^{\mathrm{a}} \pm 0.49$ \\
\hline $\mathrm{A} 45\left(\mathrm{~cm}^{2}\right)$ & $29.87^{c} \pm 3.42$ & $26.48^{c} \pm 4.16$ & $84.20^{\mathrm{b}} \pm 2.96$ & $137.37^{a} \pm 19.58$ \\
\hline A90 $\left(\mathrm{cm}^{2}\right)$ & $31.13^{c} \pm 2.74$ & $29.72^{c} \pm 3.31$ & $116.00^{\mathrm{b}} \pm 2.90$ & $168.88^{a} \pm 19.42$ \\
\hline $\mathrm{A} 135\left(\mathrm{~cm}^{2}\right)$ & $32.20^{\mathrm{c}} \pm 8.13$ & $33.85^{\mathrm{c}} \pm 4.25$ & $122.71^{b} \pm 7.61$ & $153.17^{a} \pm 5.66$ \\
\hline
\end{tabular}

Samples: BRS Louro, BRS Timbaúva, BRS Guamirim and BRS Pardela. Mean values in the same line followed by a different letter are significantly different (p $\leq$ 0.05). Farinographic properties: WA, water absorption (to the dry basis at 14\% humidity); MT, mixing time; AT, arrival time; DT, departure time; ST, stability; MTI, mixing tolerance index. Extensographic properties: $R_{m} 45$, maximum resistance to extension after 45 minutes; $R_{m} 90$, maximum resistance to extension after 90 minutes; $R_{m} 135$, maximum resistance to extension after 135 minute; $\mathrm{R} 45$, resistance to extension after 45 minutes; R90, resistance to extension after 90 minutes; R135, resistance to extension after 135 minutes; R/E45, proportional number after 45 minutes; R/E90, proportional number after 90 minutes; R/E135, proportional number after 135 minutes; A45, area after 45 minutes; A90, area after 90 minutes; A135, area after 135minutes; E45, extensibility after 45 minutes; E90, extensibility after 90 minutes; E135, extensibility after 135 minutes.

BRS Pardela presented the highest values. BRS Pardela cultivar wheat flour presented the lowest mixing tolerance index and the highest stability (Table 3). The flour from cultivar BRS Louro presented the lowest values of maximum resistance to extension, proportional number, resistance to extension, extensibility and amylase for all evaluations. Cultivar BRS Pardela presented the highest values of A45 (area after 45 minutes), A90 (area after 90 minutes) and A135 (area after 135 minutes), when compared to other cultivars. Cultivar BRS Louro presented the lowest resistance to extension when compared to cultivar BRS Pardela. BRS Louro cultivar flour presented the lowest proportional number values, while cultivar BRS Pardela presented the highest proportional number values (Table 3 ).

\section{Falling number}

The falling number for cultivars BRS Guamirim (470.50 s) and BRS Pardela (488.75 s) were statistically equivalent and higher than for cultivars ( $\mathrm{p} \leq 0.05)$ BRS Louro (430.00) and BRS Timbaúva (410.25).

\section{Rapid visco analyzer}

The maximum viscosity values of BRS Louro $(3169.50 \mathrm{cP})$ and BRS Pardela $(2853.00 \mathrm{cP}$ ) flours presented significantly higher results than BRS Timbaúva (2431.33cP) and BRS Guamirim (2261.33 cP) ( $\mathrm{p} \leq 0.05)$. BRS Timbaúva presented the lowest tRVA (time to pasting temperature) $(\mathrm{p} \leq 0.05)$
(5.95 minutes), minimum viscosity $(918.00 \mathrm{cP})$ and final viscosity $(2161.33 \mathrm{cP})$ values. BRS Louro flour $\left(60.80{ }^{\circ} \mathrm{C}\right)$ presented similar TRVA (pasting temperature) value to those of BRS Guamirim $\left(58.73^{\circ} \mathrm{C}\right)$ and BRS Pardela $\left(58.83^{\circ} \mathrm{C}\right)$, which, in turn, were higher than the one of BRS Timbaúva $\left(57.38^{\circ} \mathrm{C}\right)$. On the other hand, TRVA results of BRS Timbaúva, BRS Guamirim and BRS Pardela were statistically equivalent. For breakdown, BRS Timbaúva $(1188 \mathrm{cP})$ presented significantly higher values $(\mathrm{p} \leq 0.05)$ than the others, and BRS Guamirim $(492 \mathrm{cP})$ presented lower values. At the setback, flours of BRS Louro $(1117.50 \mathrm{cP})$ and BRS Pardela $(1139.33 \mathrm{cP})$ presented significantly higher values $(\mathrm{p} \leq 0.05)$ than the others, while the BRS Timbaúva $(918.00 \mathrm{cP})$ presented the lowest ones $(\mathrm{p} \leq 0.05)$.

\section{Gluten properties}

Two cultivars presented similar wet gluten values ( $\mathrm{p} \leq 0.05)$ : BRS Guamirim (35.50\%) and BRS Pardela (33.40\%), which were lower than in the other cultivars $(\mathrm{p} \leq 0.05)$. This behavior was also observed for the dry gluten test with BRS Guamirim (12.22\%) and BRS Pardela (11.17\%). The flours from the four cultivars presented significantly different gluten index results, with BRS Pardela (95.82) showing the highest value.

\section{Baking test}

Bread made with BRS Pardela flour presented a significantly higher specific volume (18.34) $(\mathrm{p} \leq 0.05)$ than the others. 
The crust color varied significantly ( $\mathrm{p} \leq 0.05)$ between all the analyzed bread. The lowest value was presented by BRS Louro (6.5). Break test values were significantly different beyween the bread formulations $(\mathrm{p} \leq 0.05)$. The highest break value was found in bread formulated with BRS Pardela flour (4.00). Regarding symmetry, bread formulated with the flours of the BRS Guamirim (3.50) and BRS Pardela (3.83) presented higher symmetry and were significantly different $(\mathrm{p} \leq 0.05)$ from the others. The crumb characteristic was significantly higher $(\mathrm{p} \leq 0.05)$ for the cultivar BRS Pardela bread (3.83) and lower than that of BRS Louro (1.67) and BRS Timbaúva (2.00). For the crumb color attribute, bread made with flours from cultivars BRS Guamirim and BRS Pardela were significantly higher ( $\mathrm{p} \leq 0.05)$, both around 9.00. The crumb color value was significantly lower $(\mathrm{p} \leq 0.05)$ for BRS Louro bread (6.33). The crumb cell was significantly higher $(\mathrm{p} \leq 0.05)$ in the BRS Guamirim bread (7.17), followed by bread formulated with BRS Pardela (6.33). The crumb texture presented significantly higher values $(\mathrm{p} \leq 0.05)$ for bread formulated with cultivar BRS Pardela flour (9.00) and lower than in flours from the BRS Louro (5.17) and BRS Timbaúva (5.83). According to the results, the bread flavor attribute was prominent for bread elaborated with the flours of BRS Guamirim (8.00) and BRS Pardela (9.00), being both significantly higher $(\mathrm{p} \leq 0.05)$ than the others. However, bread formulated with the flour from cultivar BRS Louro (6.5) had lower values than others for bread flavor. Taste attribute was significantly higher $(\mathrm{p} \leq 0.05)$ for bread formulated with flours from cultivars BRS Pardela (13.00) and BRS Guamirim (12.33).

\subsection{Microscopic characterization of flours}

SEM (Scanning Electron Microscopy) images of the flour samples (Figure 1) showed that BRS Louro (Figure 1a) had a high number of small starch granules type "b", which appeared with a smooth clean surface and free from the protein matrix. Flour from BRS Timbaúva (Figure 1b) also presented a high quantity of starch granules type " $b$ ", in a very compact structure and the protein matrix. BRS Guamirim (Figure 1c) presented
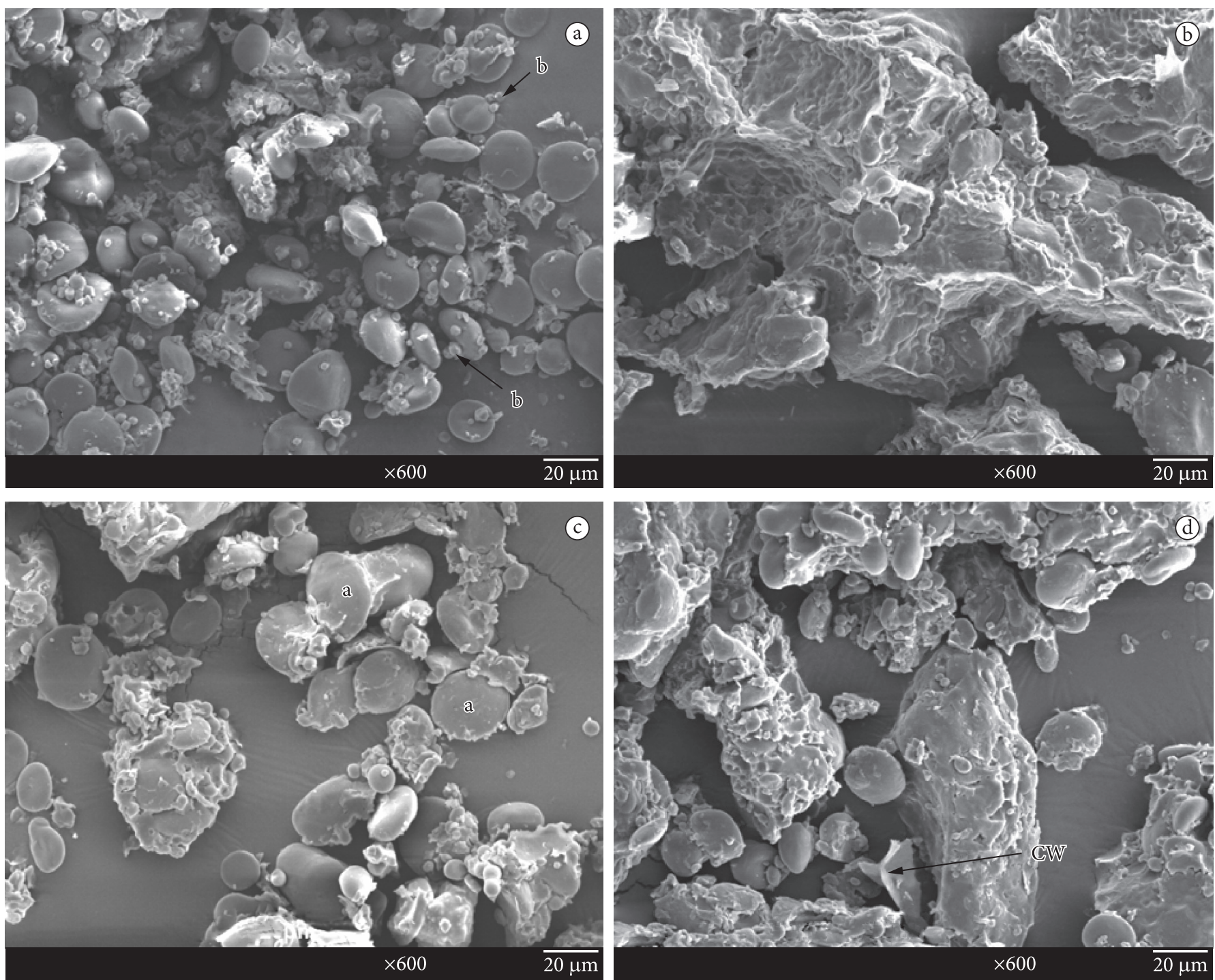

Figure. 1. Scanning electron microscopy (SEM) of wheat flour from cultivars: a) BRS Louro; b) BRS Timbaúva; c) BRS Guamirim; and d) BRS Pardela. Showing "a"- large starch granules; "b"- small starch granules (arrows) and "cw" endosperm cell walls (arrows). 
flour with small agglomerates of large (type "a") and small starch granules with remnants of the protein matrix. Flour from cultivar BRS Pardela (Figure 1d) presented a very compact structure, with obvious cell walls (cw), and apparently the same amount of starch granules "a" and "b".

\subsection{Principal component analysis}

Principal component analysis (PCA) was used in order to observe and determine the different quality characteristics of grains and flours, and the influence of cultivar.

The projection of the variables studied at the first PCA group, (Figure 2a) was defined by the first plan by two factors ( 1 and 2). These two factors accounted for about 46 and $39 \%$ of variance, respectively. Each vector represents the variables; so, the closer the vectors are to the variables the more positive the correlation between them, such as: wet gluten and dry gluten, thousand kernel weight and extraction, kernel water activity and kernel moisture, kernel hardness index and extraction, kernel hardness index and chroma $b^{*}$, and crude protein content and gluten index. The $180^{\circ}$ vectors represent variables that were negatively correlated, which was the case with gluten, crude protein, color and lipid. When the variable vectors are at right angles, they are independent. Factors 1 and 2 represented a way to differentiate between grains and flours, respectively. In fact, grain and flour samples contrasted with the variables evaluated. When Figure 2a was superimposed on Figure 2b, it was observed that BRS Louro flour had the lowest averages for wet gluten and dry gluten; therefore, the perpendicular graphical projection was below the origin. BRS Louro cultivar grain and flour presented the highest averages for color attribute chroma
$L^{*}$, lipids, kernel moisture, test weight, kernel water activity, color attribute chroma $\mathrm{a}^{*}$ and ash; thus, the perpendicular graphic projection was above the origin. In the same way, BRS Timbaúva grain and flour samples presented values above average for variables $b^{*}$, kernel hardness index, thousand kernel weight and extraction; and values below average for flour moisture and flour water activity. Regarding the starch variable, BRS Timbaúva grain and its respective flour presented average values, so, perpendicular graphic projection was similar to the origin. Similar results were obtained with the variables falling number and total dietary fiber for BRS Guamirim grain and flour. However, values for flour moisture and flour water activity were below average, and variables chroma $b^{\star}$, kernel hardness index, thousand kernel weight, extraction, starch, gluten index and crude protein content were found to be above average. Finally, BRS Pardela grain and flour showed variables total dietary fiber, falling number, crude protein content, gluten index, starch and amylose with higher values than the average.

Figure $3 \mathrm{a}$ shows positive and strong correlations between crude protein content and mixing time, stability and crude protein content, and mixing time and specific volume. Vectors were negatively correlated with water absorption and mixing tolerance index. Amylose content did not seem to be correlated with crude protein content, departure time, stability and specific volume. There were no correlations between starch and ash, or between water absorption with stability or with mixing time individually. Lipids, mixing time and stability did not show any correlations. When Figure 3a was superimposed on Figure 3b, the results showed that BRS Louro grain and flour presented the lowest values for lipids and amylose variables, and values above average for mixing tolerance index, similar to BRS Timbaúva.
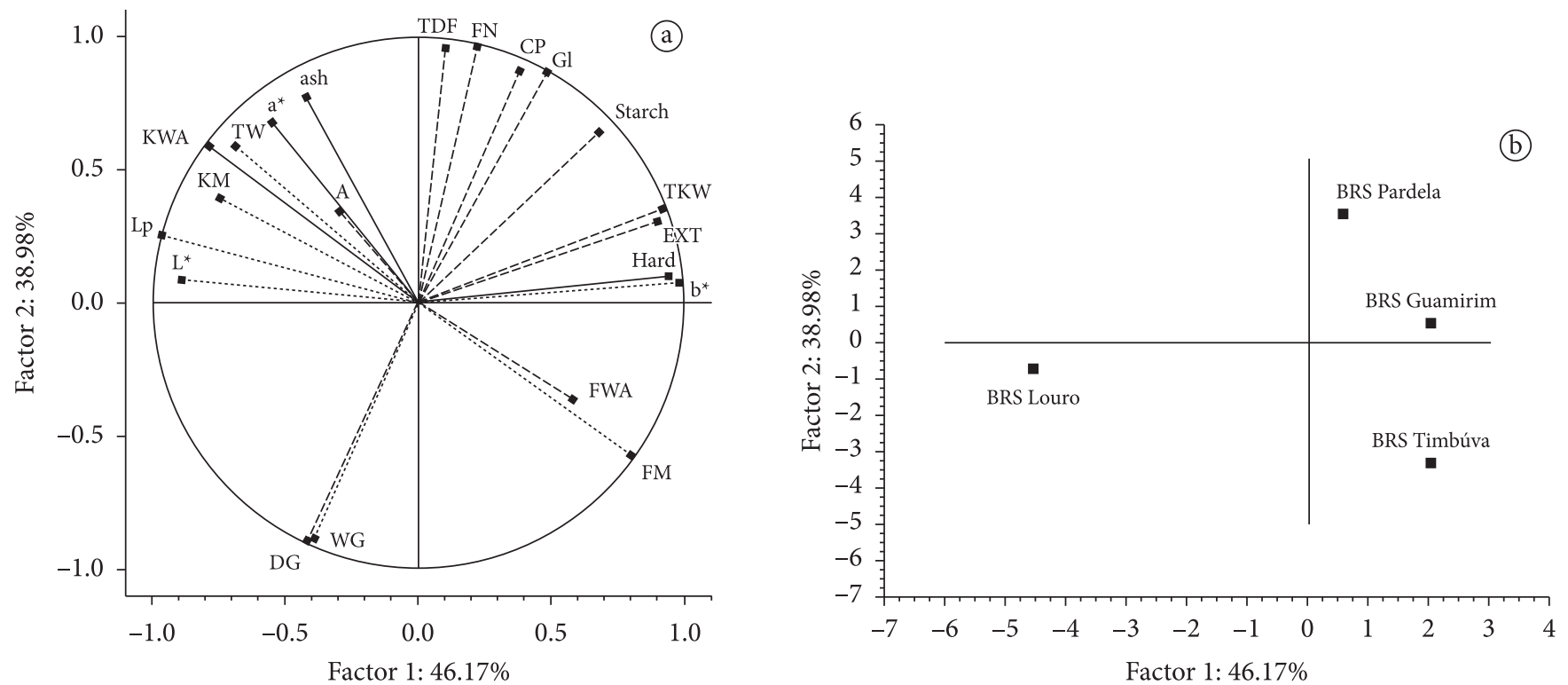

Figure. 2. a) Principal component analysis of physical characterization of grains, physical and chemical characterization of flours, gluten and falling number. Variables are: $\mathrm{L}^{\star}$, chroma $\mathrm{L}^{*}$; Lp, lipids; KM, kernel moisture; KWA, kernel water activity; TW, test weight; $\mathrm{a}^{*}$, chroma $\mathrm{a}^{\star}$; A, amylose; ash; TDF, total dietary fiber; FN, falling number; CP, crude protein; GI, gluten index; starch; EXT, extraction; TKW, thousand kernel weight; Hard, kernel hardness index; chroma $b^{*}$, chroma b*; FWA, flour water activity; FM, flour moisture; WG, wet gluten; DG, dry gluten. b) Principal component projections between physical characterization of the cultivars, physical and chemical characterization of the flours, gluten and falling number. 
BRS Guamirim grain and flour presented values above average for arrival time and starch. BRS Pardela flour presented values above average for water absorption, arrival time and starch, while total dietary fiber, crude protein content, specific volume, departure time, mixing time and stability variables presented the lowest values.

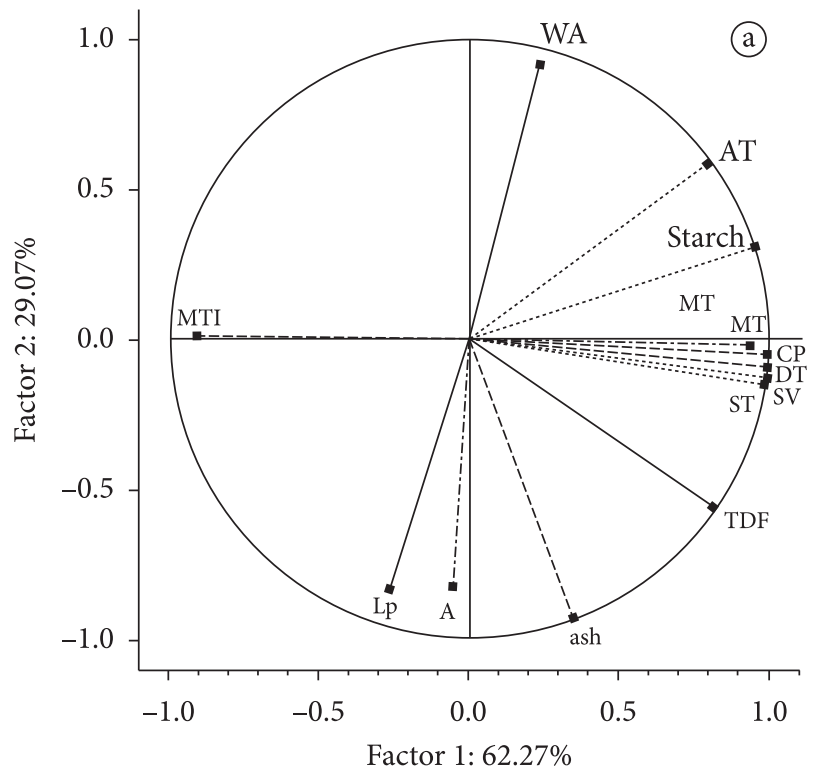

Figure 4a showed positive and strong correlations between the following group of variables: total protein content, specific volume, extensography parameters R45 (resistance to extension after 45 minutes), R90 (resistance to extension after 90 minutes), R135 (resistance to extension after 135 minutes), $\mathrm{R}_{\mathrm{m}} 45$ (maximum resistance to extension after 45 minutes), $\mathrm{R}_{\mathrm{m}} 90$ (maximum resistance to extension after 90 minutes), $\mathrm{R}_{\mathrm{m}} 135$

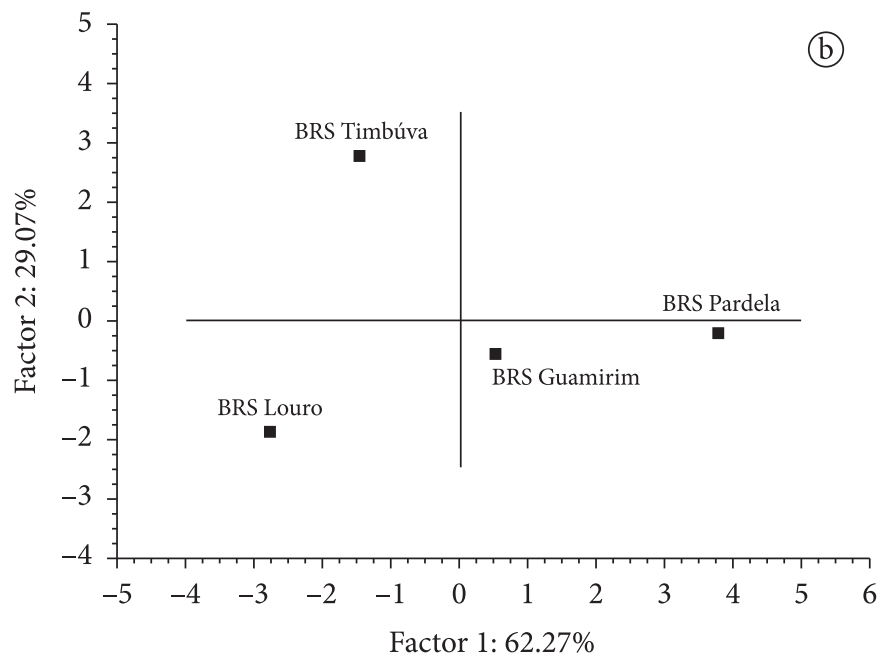

Figure. 3. a) Principal component analysis of the chemical characterization of flours, farinograph and specific volume. Variables are: MTI, mixing tolerance index; WA, water absorption; AT, arrival time; starch; MT, mixing time; ST, stability; CP, crude protein content; DT, departure time; SV, specific volume; TDF, total dietary fiber; ash; A, amylose; Lp, lipids. b) Principal component projections of chemical characterization of flours, farinography and specific volume.
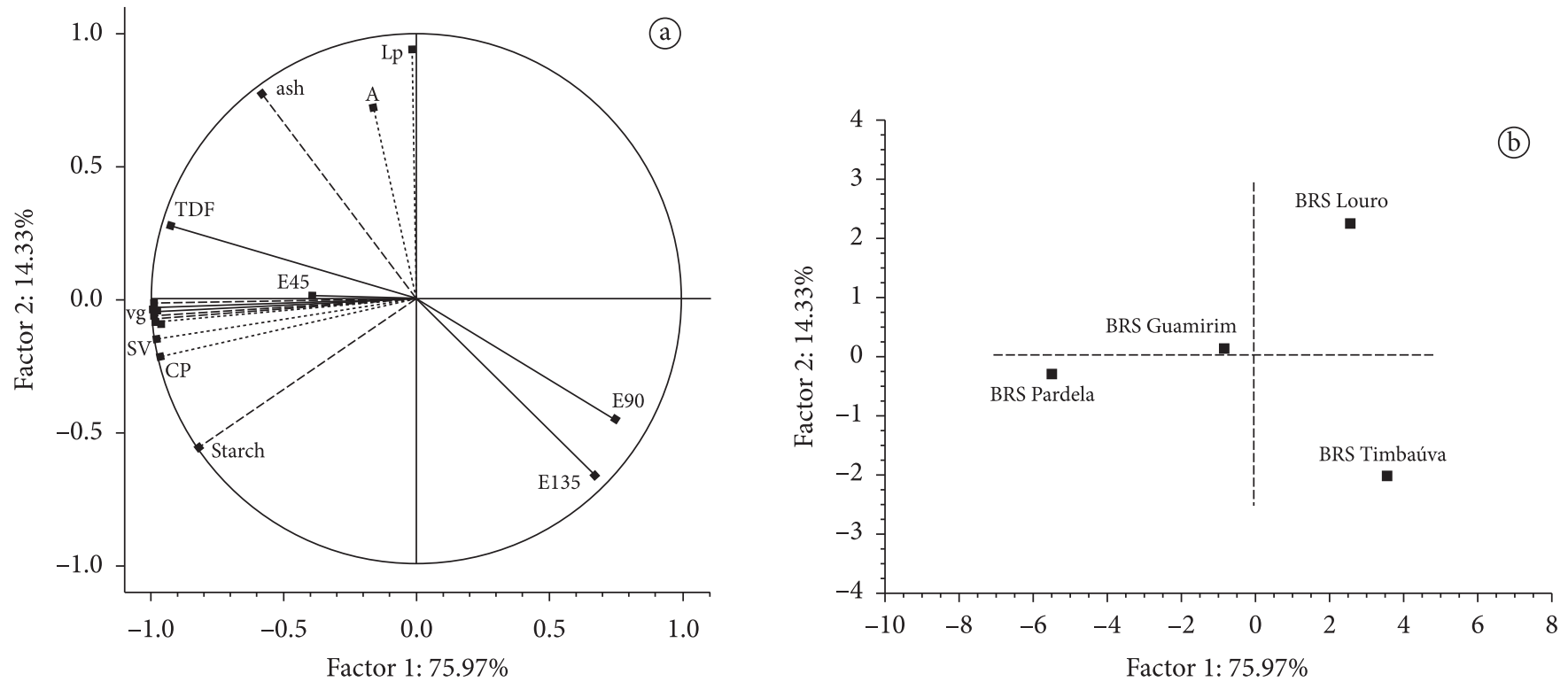

Figure. 4. a) Principal component analysis of chemical characterization of flours, extensography and specific volume. V variables are: TDF, total dietary fiber; ash; A, amylose; Lp, lipids; SV, specific volume; starch; CP, crude protein content. The variables group (vg) consists of: $\mathrm{R}_{\mathrm{m}} 45$, maximum resistance to extension after 45 minutes; $R_{m} 90$, maximum resistance to extension after 90 minutes; $R_{m} 135$, maximum resistance to extension after 135 minute; R45, resistance to extension after 45 minutes; R90, resistance to extension after 90 minutes; R135, resistance to extension after 135 minutes; R/E45, proportional number after 45 minutes; R/E90, proportional number after 90 minutes; R/E135, proportional number after 135 minutes; A45, area after 45 minutes; A90, area after 90 minutes; A135, area after 135 minutes; E45, extensibility after 45 minutes; E90, extensibility after 90 minutes; E135, extensibility after 135 minutes. b) Principal component projections of chemical characterization of flours, extensography and specific volume. 

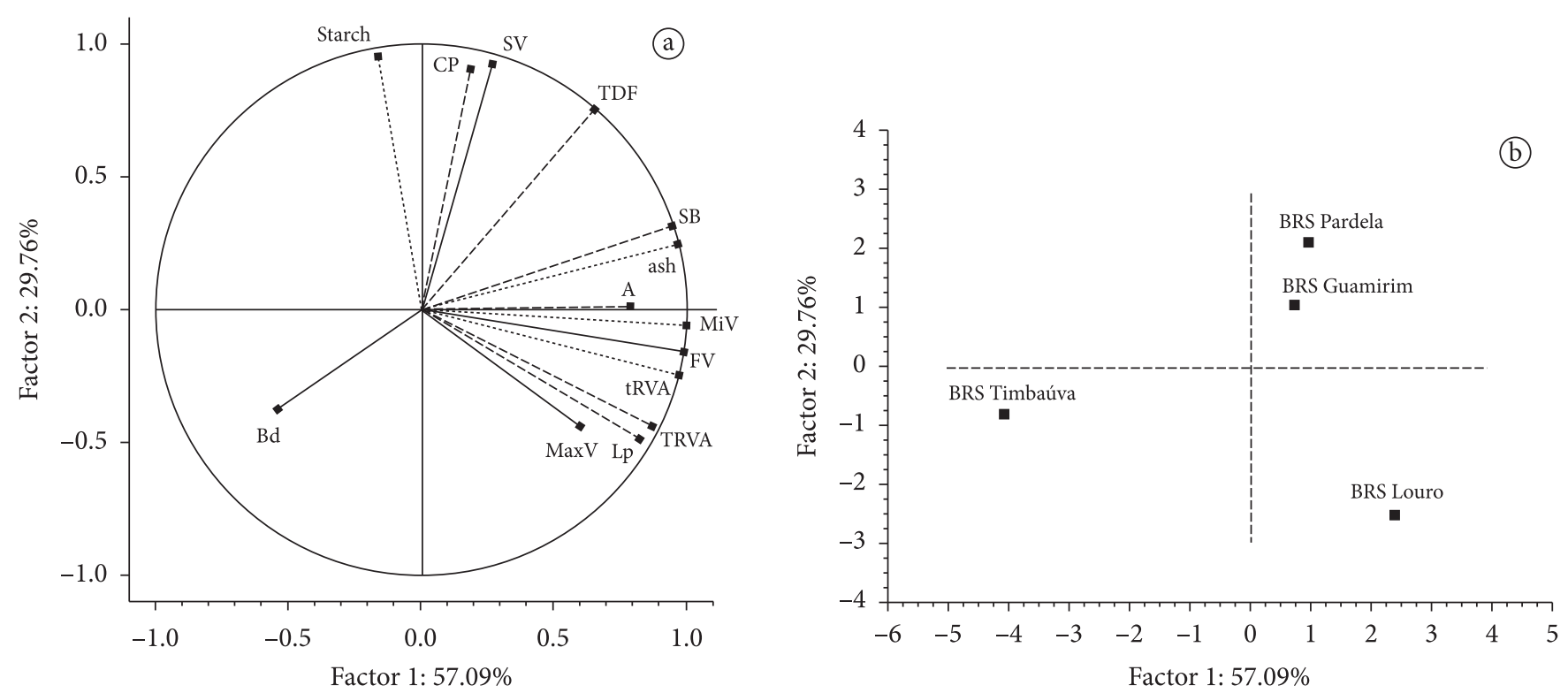

Figure. 5. a) Principal component analysis of chemical characterization of flours, RVA and baking test. Variables are: Bd, breakdown; starch; $\mathrm{CP}$, crude protein content; SV, specific volume; TDF, total dietary fiber; SB, setback; ash; amylose; MiV, minimum viscosity; MaxV, maximum viscosity; FV, final viscosity; tRVA, time to pasting temperature; TRVA, pasting temperature; Lp, lipids. b) Principal component projections of chemical characterization of flours, RVA and baking test.

(maximum resistance to extension after 135 minutes), A45, A90, A135, R/E45 (proportional number after 45 minutes), R/E90 (proportional number after 90 minutes), R/E135 (proportional number after 135 minutes), and E45 (extensibility after 45 minutes). The negatively correlated variables were ash and E135 (extensibility after 135 minutes), total dietary fiber and E135. There were some independent variables: starch did not present correlation with E135; amylose did not correlate with total protein content; correlation between ash and starch was not observed and individual correlation between lipids and R45, R90, R135, R 45, R 90, R 135 , A45, A90, A135, R/E45, R/E90, $\mathrm{R} / \mathrm{E} 135$ and $\mathrm{E} 45$ were also not observed. BRS Timbaúva cultivar presented the lowest value for variables E90 (extensibility after 90 minutes) and E135. BRS Pardela cultivar flour presented the highest values for total dietary fiber and ash, and the lowest values for starch, crude protein content, specific volume, R45, R90, R135, $\mathrm{R}_{\mathrm{m}} 45, \mathrm{R}_{\mathrm{m}}$ 90, $\mathrm{R}_{\mathrm{m}}$ 135, A45, A90, A135, R/E45, R/E90, $\mathrm{R} / \mathrm{E} 135$ and E45. When Figure $4 \mathrm{a}$ was superimposed on Figure $4 \mathrm{~b}$, results showed that BRS Timbaúva presented the lowest values for variables E90 and E135. Flour from BRS Pardela presented the highest values for total dietary fiber and ash, and the lowest values for starch, crude protein content, specific volume, R45, R90, R135, $\mathrm{R}_{\mathrm{m}} 45, \mathrm{R}_{\mathrm{m}} 90, \mathrm{R}_{\mathrm{m}} 135, \mathrm{~A} 45, \mathrm{~A} 90, \mathrm{~A} 135$, R/E45, R/E90, R/E135 and E45.

Figure 5a shows positive and strong correlations between final viscosity and tRVA, and between amylose and minimum viscosity. There were negative correlations between the variables breakdown and total dietary fiber, and breakdown and setback. Variables starch and ash, total protein content and final viscosity, specific volume and tRVA presented independence of each other. When Figure 5 a was superimposed onto Figure 5b, results showed that BRS Louro flour was below average for maximum viscosity, lipids, TRVA, tRVA, final viscosity, and amylose. Flour from BRS Timbaúva presented the lowest values for breakdown. BRS Pardela flour presented the highest values for total dietary fiber, specific volume, total protein content, setback and ash. For BRS Pardela, variables amylose, minimum viscosity, final viscosity, tRVA, TRVA, lipids and maximum viscosity presented values below average.

\section{Discussion}

According to the falling number values obtained, all samples evaluated in the present work presented low amylolitic activity, making them suitable for the study.

Cultivar BRS Louro presented the lowest thousand kernel weight, and its kernel hardness index defined it as a semi-soft kernel, with the lowest extraction and the highest kernel water activity when compared to the other cultivars. These attributes suggest a higher water absorption capacity during tempering for subsequent milling and lower wheat flour production yield, with larger flour particles.

The flour from the cultivar BRS Louro was the whitest one, it presented amylose value below average, with the lowest total protein content and water absorption, when compared to flours from the other cultivars. Low total protein content can be associated with low water absorption, as previously discussed by Chiang, Chen and Chang (2006) in a similar article with different wheat cultivars. Low total protein content has also been related to poor baking quality (JANSSEN; VANVLIET; VEREIJKENS, 1996), what was observed when comparing the total protein content and bread specific volume of flour from cultivar BRS Louro.

Flour with weak gluten presents poor water absorption and stability in comparison to stronger gluten flour (NORTH 
AMERICAN EXPORT GRAIN ASSOCIATION, 2008), this fact was observed for the flours from cultivars BRS Louro and BRS Pardela, respectively.

BRS Pardela cultivar presented higher test weight, kernel hardness index and extraction than the other cultivars. Values for total dietary fiber, falling number, total protein content, gluten index, starch and amylase were also above average.

The presence of band $5+10$ with SDS-PAGE was previously associated with suitable bread-baking quality (MANN et al, 2009). BRS Pardela was the only cultivar that presented this band, which seemed to be related to the greatest dough elasticity values and highest gluten strength of cultivar BRS Pardela. The $17+18$ band, also related to bread quality flour (XU et al., 2008), was also found in BRS Pardela.

Once dough rheology is influenced by physicochemical attributes, the interaction between variables can be useful for the suggestion of cultivars for specific end-uses. The lowest values for water absorption, mixing time, arrival time, departure time, stability, resistance to extension, extensibility, amylose and crust color found in BRS Louro characterize it as a cultivar with weak gluten.

The lowest mixing tolerance index (40.00 FU) and the highest value for stability (14.7 minutes) make BRS Pardela a satisfactory choice for bread-baking. Values for water absorption, arrival time, amylose, resistance to extension, stability, break, symmetry, crust characteristic, crumb texture, and flavor of this cultivar were similar to the average.

The lowest values of resistance to extension, extensibility and area (A45, A90 and A135), found in BRS Louro flour, reveal a weak interaction between the protein molecules of this sample. Similar observations were reported by Chiang, Chen and Chang (2006).

Flour with weak gluten has short resistance to extension when compared to strong gluten flour (POPPER; SCHÄFER; FREUND, 2006). This fact was observed with BRS Louro and BRS Pardela, respectively.

As the $\mathrm{R} / \mathrm{E}$ increases, the dough tendency decreases. And as the $\mathrm{R} / \mathrm{E}$ decreases, the dough tendency increases. Generally, strong flours present $\mathrm{R} / \mathrm{E}>2.5$ and weak flours present $\mathrm{R} / \mathrm{E}<1.0$ (MONTENEGRO; ORMENESE, 2008). This behavior was verified for BRS Pardela and BRS Louro, respectively. Besides greater extensibility, better flour has high resistance to extension (KOKELAAR; VANVLIET; PRINS, 1996), as observed with BRS Pardela.

Specific bread volume is affected by the total protein content of the wheat flour (FINNEY, 1984) which was confirmed by the largest bread specific volume (18.34) and total protein content (14.35\%) of BRS Pardela.

The results from BRS Timbaúva grain and its respective flour were not sufficiently consistent to give a clear indication for technological applicability, as well as the results from cultivars BRS Louro and BRS Pardela. BRS Timbaúva presented similar characteristics to BRS Louro regarding falling number and viscosity. On the other hand, it showed similarities with
BRS Pardela cultivar concerning kernel hardness index, which defined it as a hard grain which allows water absorption to make viscoelastic dough.

The characterization of BRS Guamirim was similar to BRS Timbaúva, once their variables did not allow a clear technological indication. Cultivar BRS Guamirim presented values above average for kernel hardness index, thousand kernel weight, extraction, chroma $b^{*}$, starch, amylose, ash, gluten index, crude protein content and arrival time. According to the rheological analysis and baking test, the dough from BRS Guamirim could be characterized as extensible and elastic, for bread with good quality attributes such as crumb color, crumb cell, taste and flavor.

\section{Conclusions}

This study led to a better understanding of the interactions between wheat physical characteristics, chemical composition, storage protein extraction and microstructure, which define flour quality in terms of rheological attributes for a specific end use of four Brazilian cultivars: BRS Louro, BRS Timbaúva, BRS Guamirim and BRS Pardela. Considering the four cultivars studies, BRS Pardela seemed to have characteristics of hard wheat, being more appropriate for bread flour. On the other hand, BRS Louro could be characterized as a semi-soft grain with low crude protein content, poor gluten strength and poor baking qualities, suitable for sugar containing products such as cookies, cakes and pies. The other two cultivars: BRS Timbaúva and BRS Guamirim presented average values and could not be clearly indicated for a specific technological application, as there were discrepancies between the obtained results. However, BRS Guamirim may have application in baking products. The results from BRS Timbaúva were the least conclusive; it may have some general application for cookies and extruded products.

\section{References}

AMERICAN ASSOCIATION OF CEREAL CHEMISTS INTERnATIONAL. Approved Methods of the American Association of Cereal Chemists. 10th ed. St. Paul: AACC, 2000.

BLAKESLEY, R. W.; BOEZI, J. A. A new staining technique for proteins in polyacrilamide gels using Coomassie Brilliant Blue G250. Analytical Biochemistry, v. 82, p. 580-582, 1977. http://dx.doi. org/10.1016/0003-2697(77)90197-X

BRASIL. Ministério da Agricultura e Reforma Agrária. Regras para análise de sementes. Brasília: MARA/ACS, 1992.

CAMARGO, C. R. O; CAMARGO, C. E. G. Trigo: Avaliação tecnológica e novas linhagens. Bragantia, v. 46, p. 81-169, 1987.

CHIANG, S.; CHEN, C.; CHANG, C. Effect of wheat flour protein compositions on the quality of deep-fried gluten balls. Cereal Chemistry, v. 97, p. 666-673, 2006.

CURTIS, B. C.; RAJARAM, S.; MACPHERSON, H. G. Bread Wheat - Improvement and Production. Roma: FAO, 2002. (FAO Plant Production and Protection Series).

EL-DASH, A. A. Standardized mixing and fermentation procedure for experimental baking test. Cereal Chemistry, v. 55, p. 436-446, 1978.

FINNEY, K. L. Na optimized straight-dough breadmaking procedure after 44 years. Cereal Chemistry, v. 61, p. 20-27, 1984. 
GILBERT, G. A.; SPRAGG, S. P. Iodine Sorption: Blue Value. In: WHISTLER, R. L. et al. (Eds.). Methods in Carbohydrate Chemistry. London: Academic Press, 1964.

HOSENEY, R. C. Principios de ciencia y tecnologia de los cereales. Zaragoza: Acribia, 1991.

JANSSEN, A. M.; VANVLIET, T.; VEREIJKENS, J. M. Fundamental and Empirical Rheological Behaviour of Wheat Flour Doughs and Comparison with Bread Making Performance. Journal of the Cereal Science, v. 23, p. 43-54, 1996. http://dx.doi.org/10.1006/ jcrs.1996.0004

KOKELAAR, J. J.; VANVLIET, T.; PRINS, A. Strain Hardening Properties and Extensibility of Flour and Gluten Doughs in Relation to Breadmaking Performance. Journal of Cereal Science, v. 24, p. 199-214, 1996. http://dx.doi.org/10.1006/jcrs.1996.0053

MANN, G. et al. Genetic control of wheat quality: interactions between chromosomal regions determining protein content and composition, dough rheology, and sponge and dough baking properties. Theoretical and Applied Genetics, v. 118, p. 15191537, 2009. PMid:19283360. http://dx.doi.org/10.1007/s00122009-1000-y

MONTENEGRO, F. M.; ORMENESE, R. C. S. Avaliação da Qualidade Tecnológica da Farinha de Trigo. Campinas: Cereal Chocotec ITAL, 2008.

MORITA, N. et al. Dough and baking properties of highamylose and waxy wheat flours. Cereal Chemistry, v. 79, p. 491-495, 2002. http:// dx.doi.org/10.1094/CCHEM.2002.79.4.491

MOUSIA, Z. et al. Effect of wheat perling on flour quality. Food Research International, v. 37, p. 449-459, 2004. http://dx.doi. org/10.1016/j.foodres.2004.02.012
NEWPORT scientific method ST-00. Revision 3. Decatur: A. E. Staley Manufacturing Co., 1998. IL 62525.

NORTH AMERICAN EXPORT GRAIN ASSOCIATION - NAEGA. Wheat and Flour Testing Methods: A Guide to Understanding Wheat and Flour Quality: Version 2. Wheat Flour Testing Book. Disponível em: <www.wheatflourbook.org>. Acess: 10 mar. 2009.

PAYNE, P. I.; LAWRENCE, G. J. Catalogue of alleles for the complex gene loci, Glu-A1, Glu-B1, and Glu-D1 which code for highmolecular-weight subunits of glutenin in hexaploid wheat. Cereal Research Communications, v. 11, p. 29-35, 1983.

POPPER, L.; SCHÄFER, W.; FREUND, W. Future of Flour - A Compendium of Flour Improvement. Kansas City: Agrimedia, 2006.

SINGH, N.; SHEPHERD, K. W.; CORNISH, G. B. A Simplified SDSPAGE Procedure for Separating LMW Subunits of Glutenin. Journal of Cereal Science, v. 14, p. 203-208, 1991. http://dx.doi.org/10.1016/ S0733-5210(09)80039-8

SONG, Y.; ZHENG, Q. Dynamic rheological properties of wheat flour dough and proteins. Food Science \& Technology, v. 18, p. 132-138, 2007.

TORRES, G. A. M. Proteínas de reserva do trigo: o pão ou o biscoito nosso de cada dia. AGROLINK, 2008. Disponível em: <www.agrolink.com.br/cereaisdeinverno/NoticiaDetalhe. aspx? codNoticia=62613>. Acesso em: 20 jan. 2009.

$\mathrm{XU}$, W. et al. PCR-based markers for identification of HMW-GS at Glu-B1 $x$ loci in common wheat. Journal of Cereal Science, v. 47, p. 394-398, 2008. http://dx.doi.org/10.1016/j.jcs.2007.05.002 
